\title{
Competitiveness And Innovativeness In The Attractiveness of A Tourist Destination Case Study - Tourist Destination Oltenia
}

\author{
Mirela Mazilu \\ University of Craiova, \\ Str. Alexandru Ioan Cuza 13, Craiova 200585, Romania \\ Roxana Marinescu \\ University of Craiova, \\ Str. Alexandru Ioan Cuza 13, Craiova 200585, Romania \\ Dumitru Bălă \\ University of Craiova, \\ Str. Alexandru Ioan Cuza 13, Craiova 200585, Romania \\ Loredana Dragomir \\ University of Craiova, \\ Str. Alexandru Ioan Cuza 13, Craiova 200585, Romania
}

\begin{abstract}
Competitiveness together with innovation are printed on all components of a tourist destination, from the tourist product to the elements of attraction, infrastructure, entertainment, human resources, image and character, not forgetting the price that can launch or restrict it on a dynamic tourist market where quality overtakes in recent years and meets dynamic tourist demand. This article aims to analyze the two imperative components in the sustainable functionality of a tourist destination, inseparable binomial, competitiveness and innovation as the only viable ways of halting the decline in the lifecycle of a tourist destination Oltenia. The article also attempts to apply for the Oltenia region the criteria for denominate a tourist destination in the optics of regional competitiveness and more, a tourist destination which is unfortunately currently not competitive, although it has the necessary parameters for identifying competitiveness (natural and cultural resources, customs and traditions, unique local products, tourist identity, etc.). Through specific geographical methods (diagnosis, prospective, documentary, graphical representation, and also Butler's TALC model) the article sets out a complex theoretical and methodological framework, with factual determinations in promoting the destination Oltenia as a destination of excellence in Romania (The Danube Gorge may be considered as the region's visiting card, being thus awarded the title of "European Destination of Excellence" in 2008).
\end{abstract}

Keywords: competitiveness, identity, innovation, tourist product, tourist destination.

\section{INTRODUCTION}

The competitiveness of European tourism is desired to be closely linked to its sustainability, as the quality of the tourist destination is strongly influenced by the natural and cultural environment and by the way it is integrated into the local community, according to the European Commission initiatives. [1] 
As it has been highlighted by several researchers [2], [3], [4], [5], the sustainable development is a precondition for competitiveness. "Without sustainability, competitiveness is just an illusion".

Poon [6] has identified 4 basic principles that tourism destinations should comply with in order to be competitive on the international market, namely: emphasis on environmental protection, granting of a priority economic role for tourism, improving the means of distribution on the market and building and maintaining a very dynamic private sector. Competitiveness of a tourist destination evolves subject to several factors such as a highly competitive market, a consistent pricing policy, the cutting-edge performance technologies, all of them ensuring, via a rigorous marketing policy, a sustainable competitive development in order to meet the motivations and expectations of tourists, according to a cycle of interconditions, which must be respected in order to be deemed a competitive tourism destination (Figure. 1).

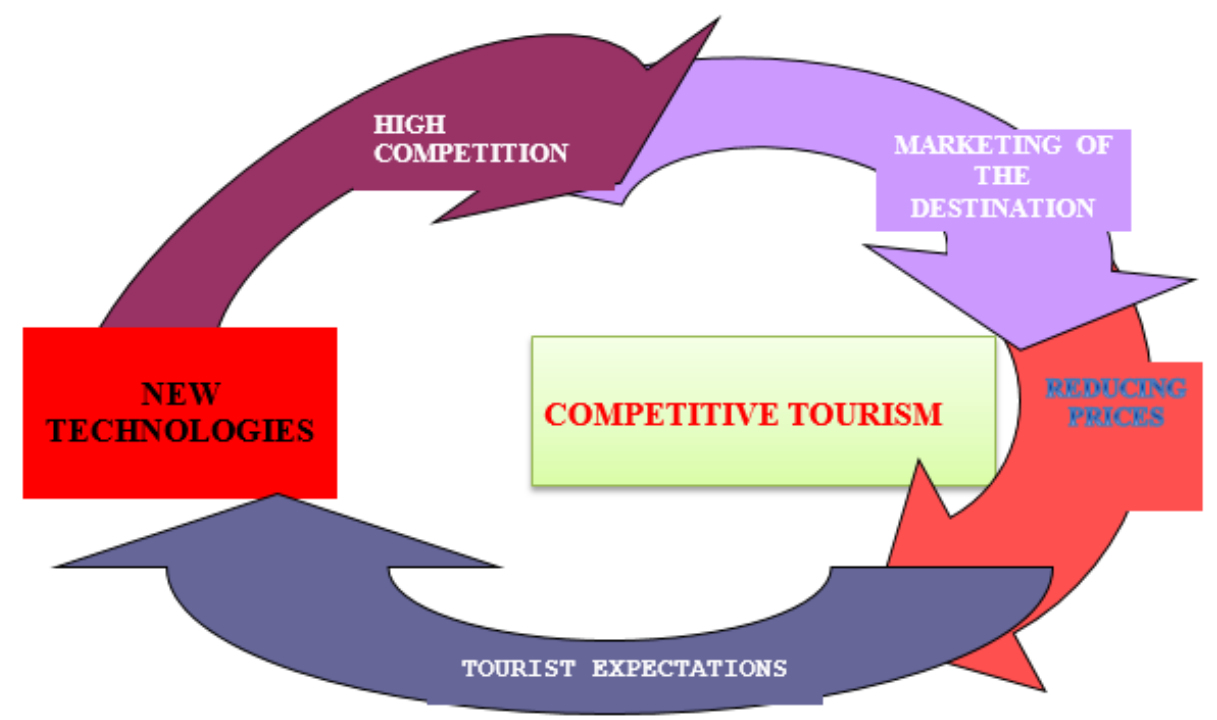

Figure 1 Cycle of Competitiveness of a Tourist Destination - Required Stages (Source: adaptation by PricewaterhouseCoopers research, 2004.)

Mihalic Tanja argues that "attractiveness and competitiveness of the destination can be increased by properly managing the environmental quality of the destination"[7]. She maintains "the fact that destination competitiveness can be improved through initiatives such as codes of conduct, self-developed environmental practices, certified and award-based best practices and accreditation and, in many cases, environmental objectives and practices must be incorporated into current attitudes, destination management, strategies and methods for the stated purpose that those destinations remain competitive, maintaining a high level of environmental quality is also important for the competitiveness of most types of tourist destinations and, therefore, a primary concern for destination managers "[7].

A detailed analysis of competitiveness of tourist destinations has been carried out by Ritchie \& Crouch since 1993 [8], these researchers continually developing and improving a conceptual model of competitiveness and sustainability for tourist destinations that includes five determinants: the main resources and attractions; the relevant factors and support resources; strategy, planning and destination development; destination management; qualitative determinants and amplifiers. 
Resources and main attractions are in fact one of the 5 pillars of the sustainable competitive destination model, including the primary elements that ensure the attractiveness of the destination, these factors motivating tourists to visit that particular destination (Figure 4).

These resources are grouped into seven categories: landscape and climate, culture and history, market ties, mix of activities, special events, spending time and specific tourist infrastructure (Figure 2).

The attractions of a tourist destination are diverse and spatially grouped to assist the trips and voyages as well as to provide marvelous life experiences, spiritual enrichment, special knowledge. They are usually mingled with other leisure and holiday-related activities, such as shopping, catering and wellness services etc. Practically, a tourist destination that will provide for tourists a unique life experience, proposing something different from the daily routine, will have a competitive advantage [3]. In our case, traditions, local gastronomy, the folk suits, the elements of history, language, religion, special architecture, folk crafts are able to offer unique experiences.

These are often the focus of visitor attention and provide the initial motivation for the tourist to visit the destination. They can be: natural, built or cultural elements.

The mix of activities developed in the tourist destination has a significant contribution to increase the attractiveness of a destination, if performance management is regularly carried out.

Supporting factors and resources make a reference to the general infrastructure, accessibility to that destination, but also to the resources that determine and support the development of tourism: human capital, financial capital, skills in the field, hospitality, entrepreneurship and, last but not least, government involvement.

The strategy, planning and development of the tourist destination implies that the stakeholders manage the sustainable function of the destination to acquire and voluntarily approach the destination's identity, based on real, palpable values, so as to benefit from an appropriate positioning and branding strategy, continuous analyzes of destination competitiveness, monitoring and evaluation of the destination.

The management of the tourist destination aims at organizing the marketing actions, permanently increasing the quality of the tourist services, launching some research programs on the key aspects of the destination organization, human resources, tourists' management, as well as the crisis situations.

Qualitative determinants and amplifiers places the tourist destination onto the orbit of the main emitter markets and main competitors, providing higher safety / security, cost / value, interdependencies, positive image and support capabilities.

A tourist destination with its own identity, with its own vision of tourism development, attended by all those involved in its sustainable management, who knows and recognize very well its weaknesses and strengths will develop an adequate strategy for sustainability marketing.A tourist destination cannot become competitive outside the notion of accessibility to / within a destination. 
Unfortunately, accessibility does not work at optimal parameters for many tourist destinations due to poor, defective, poor quality infrastructure. Lack of airports, highways, speed roads to facilitate access to tourist destinations in Romania (the case of the Prahova Valley, not solved either in the year of 2019, traffic jams that are difficult to "digest" for a leisurely tourist....).

Thus, the infrastructure sums up all the assets and means through which the attractive resources of a territory are exploited in tourism [9]. This is also called the technical-material basis, being included in the tourist offer of a destination. Its primary function is to satisfy the tourist demand through specific facilities and services.

Tourist infrastructure includes [10]: accommodation and catering establishments; facilities for treatment and recreation; auxiliary (complementary) facilities; roads and means of transport.

The degree of accessibility in the tourist destination Oltenia, ensures (with small differences between counties) an optimal way of making the trip, that is to say, that segment of the recreational act without which tourism does not exist. We can see this in Figure 2, here being represented the communication routes specific to the Oltenia region, where we can observe a shortage of the railways, but also of the European roads, which pass through a small number of cities.

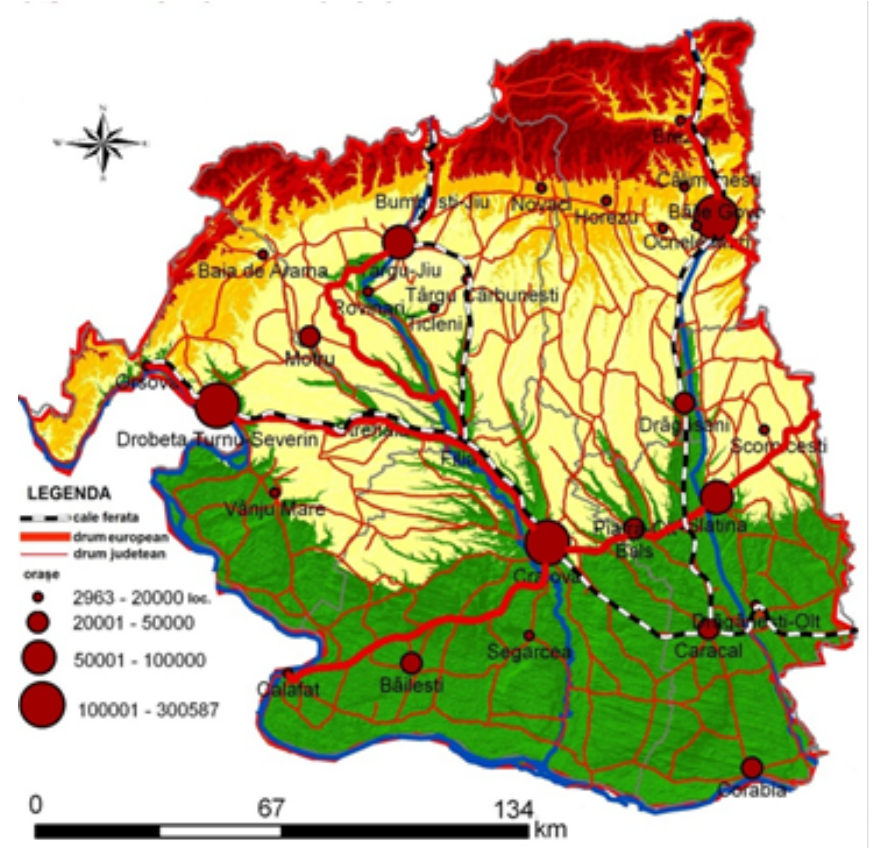

Figure 2 Communication routes in the South-West Oltenia Development Region Source:[11], (p.49)

\section{MATERIALS AND METHODS}

The purpose of this paper is to analyze the two imperative components in the sustainable functionality of a tourist destination, competitiveness and innovation as the only viable ways of halting the decline in the lifecycle of the tourist destination Oltenia.

The overall goal of a strategy for the competitiveness of Oltenia tourism destination is the increase in living standards, development and competitiveness being considered the most important parameters for economic progress. Growth involves increasing jobs in tourism, production, investment, while competitiveness is about wage growth, investment efficiency, sustainability, and, above all, productivity. This approach aims at improving the living standards of the population as a result of the development of the competitiveness of the 
regional economy. From this point of view, in this article we believe that the tourist phenomenon should not be restricted to natural and anthropic attractions, here the phenomenon of expanding-stretch-based and on the development of the knowledge of competence, on the efficiency of the tourist act, resulting in that "matching", that equilibrium and permanent adaptation to the needs of the tourists, continuously diversifying the tourism products, thus bringing true significance to the tourist destination value chain alongside the diversification of the primary and secondary functions in the optics of the two "engines" of the sustainability of a tourist destination: competitiveness and innovation.

Methodological, we have used specific methods of geography: rigorous documentation and graphical presentation of the phenomena we have analyzed and Butler's TALC Model was used to shape future trends of the destination. We applied the TALC model as a framework for analyzing a destination have identified other issues that drive change within a destination and thus influence the evolution of the destination.

Starting from the theoretical model of the tourism destination's competitiveness, we will conduct a perceptual study to determine the competitiveness of the Oltenia region as a tourist destination. This is why the TALC provides a useful descriptive tool for analyzing the development of destinations and the evolutions of their markets. In the research of this article, we complied with the following imperative steps:

of Establishing the model of a competitive tourist destination, which also implies the creation of a tourism development strategy, will be the starting point for a wider research in this article that analyzes the relative importance of the various dimensions of competitiveness (for example, how important are natural and anthropic tourism resources compared to local community hospitality, how important are the prices compared to the quality of services), focusing on tourist preferences and the factors that determine the decision to travel and choose a destination;

or Creating an image concept and message promoting the destination Oltenia;

or The development of innovative tourism products, an operation connected to the concept of tourist recreation that will amplify the frequency of tourist flows and unforgettable holidays in this destination. By creating and testing a competitive destination model, we will identify the weaknesses of the region from a tourist point of view, transformed by concerted efforts at strong points, the creation of a regional tourist brand, including the destination of the study as a tourist destination, elements with immediate effect in identifying it.

of By triggering innovative programs and common, complex and coherent, regional tourist packages, which will make use of tourism resources in the whole region, and not only punctually, at the level of a tourist destination, a city or an area, will increase the number of tourists, the duration of the stay and, implicitly, (the direct and indirect) revenues from tourism.

\section{RESULTS}

Taking into account the characteristics of road transport such as reduced transport capacity, high mobility degree, reduced comfort but economically from a financial point of view, at the level of the region, the road accessibility is done through European roads E70, E79 and E81, European transport TEN axes: axis 7 (Pan-European Corridor IV: Berlin / Nurenburg - Prague Budapest - Constanta - Istanbul - Thessaloniki) and axis 8 (Danube Corridor VII), with a total of $10460 \mathrm{~km}$.

Regarding the length of the public roads, the statistical data show a slight increase in the period 1990-2013, the highest values being recorded in the counties Dolj and Olt, the last being 
the Mehedinţi county. Awareness of the importance of accessibility by county authorities and access to European investment funds in transport infrastructure has given rise to increased attention in this transport sector (Table 1).

Table 1

The length of public roads in South-West Oltenia region (km)

\begin{tabular}{|l|c|c|c|c|c|c|}
\hline & \multicolumn{2}{|c|}{ National } & \multicolumn{2}{c|}{ County and communal } & \multicolumn{2}{c|}{ Total } \\
\hline & $\mathbf{1 9 9 0}$ & $\mathbf{2 0 1 3}$ & $\mathbf{1 9 9 0}$ & $\mathbf{2 0 1 3}$ & $\mathbf{1 9 9 0}$ & $\mathbf{2 0 1 7}$ \\
\hline $\begin{array}{l}\text { SOUTH-WEST } \\
\text { OLTENIA } \\
\text { Region }\end{array}$ & 1933 & 2178 & 8018 & 9050 & 9951 & 11228 \\
\hline Dolj & 424 & 473 & 1692 & 1962 & 2116 & 2435 \\
\hline Gorj & 342 & 426 & 1544 & 1848 & 1886 & 2274 \\
\hline Mehedinți & 376 & 449 & 1502 & 1423 & 1878 & 1872 \\
\hline Olt & 301 & 301 & 1742 & 2027 & 2043 & 2328 \\
\hline Vâlcea & 490 & 529 & 1538 & 1790 & 2028 & 2319 \\
\hline TOTAL & $\mathbf{1 4 6 8 3}$ & $\mathbf{1 7 1 1 0}$ & $\mathbf{5 8 1 3 3}$ & $\mathbf{6 7 7 7 7}$ & $\mathbf{7 2 8 1 6}$ & $\mathbf{8 4 8 8 7}$ \\
\hline
\end{tabular}

Source: The National Institute of Statistics (NSI), 2017

Transport by rail is a fast and usable medium in all seasons, for all ages, favoring mass tourism. In addition to the constant speed and average transport capacity, there is also the safety of the trip, high comfort and regularity of the railway traffic. The M900 and M902 buses, with the Craiova railway hub, provide access to the area for tourists, although the $1000 \mathrm{~km} 2$ rail density is among the lowest in the country.

At the regional level there is a decrease in the length of the railways in operation since 1990 in 2017, most of the counties registering decreases in these values or insignificant increases (Table 2).

Table 2

The length of the railways in operation in the South-West Oltenia Region (km)

\begin{tabular}{|l|c|c|}
\hline & \multicolumn{2}{|c|}{ Railways } \\
\hline $\begin{array}{l}\text { SOUTH-WEST } \\
\text { OLTENIA Region }\end{array}$ & 1990 & $\mathbf{2 0 1 7}$ \\
\hline Dolj & 1016 & 988 \\
\hline Gorj & 221 & 225 \\
\hline Mehedinț & 269 & 239 \\
\hline Olt & 129 & 124 \\
\hline Vâlcea & 233 & 237 \\
\hline
\end{tabular}

Source: The National Institute of Statistics (NSI), 2017

Air transport with its facilities at airports, represents real poles of tourism, offering tourists a wide range of services; hotels, restaurants, cinemas, railway stations, various recreational centers, etc. Air transport also adapts to the developmental features of the tourism phenomenon.

In the Oltenia region there is only one airport, Craiova International Airport, which until 2017 had regional and national importance, with international passenger transport values ranging from 740 in 2008 to 5655 in 2011 for boarding and passenger landings between 1231 in 2008 and 6213 in 2011. From 2013, the number of passenger flows has increased (still dominating the domestic ones) due to the introduction of Low-Cost Wizz Air operating in the center, west and south of Europe in London, Milan, Rome, Bologna, Dortmund, Barcelona [12]. 
Naval transport ensures on the one hand the movement of the tourists from one place to the other and the proper recreation yacht, with the possibility of developing the cruise tourism in the region, the Danube is the main river artery along which are located the harbors: Drobeta Turnu-Severin, Calafat, Corabia, Bechet etc. The construction of the Calafat-Vidin Bridge is an advantage for the Bulgaria-Romania circulation, the bridge also connecting the areas in southern Europe.

Thus, the tourist accessibility in the area has led to the creation of the traffic circles, namely the domestic and international tourist access points of the tourists.

There is a national access corridor in the analyzed area, but there is a potential for access of foreign tourists in the region, who can opt for the means of road, air or naval.

Butler's TALC model was used to outline future destination trends. According to its model, a tourist destination goes through several stages of development, namely: exploration stage (with a small number of tourist arrivals), stage of development (when there are improved the tourist attractions and facilities); the stagnation stage (when a certain reception capacity is reached); the regeneration-trajectory stage $\mathrm{C}$ (when developments or investments are made in the tourist reception capacity), the stage of destruction of tourist resources and the stage of decline-trajectory D (when a crisis affects tourist activity) [13]. The model also has limitations because in reality it is difficult to demarcate these periods / stages of development of a destination, most of the time there are overlaps.

The TALC model developed for the destination Oltenia (Figure 3) for the period 1990-2013 shows that the destination has undergone an exploration and development stage in 19901992, then crossed a consolidation period until 1996, followed by a stage of stagnation that stretches over a long period until 2008. After this period, the destination Oltenia is currently in the stages corresponding to the $\mathrm{C} / \mathrm{D}$ trajectories, which means that the tourism in the region may be an alternative for the regeneration of the area or, by the contrary, the economic and social crisis are likely to affect the tourism resources, and therefore, the tourism development will not be sustainable.

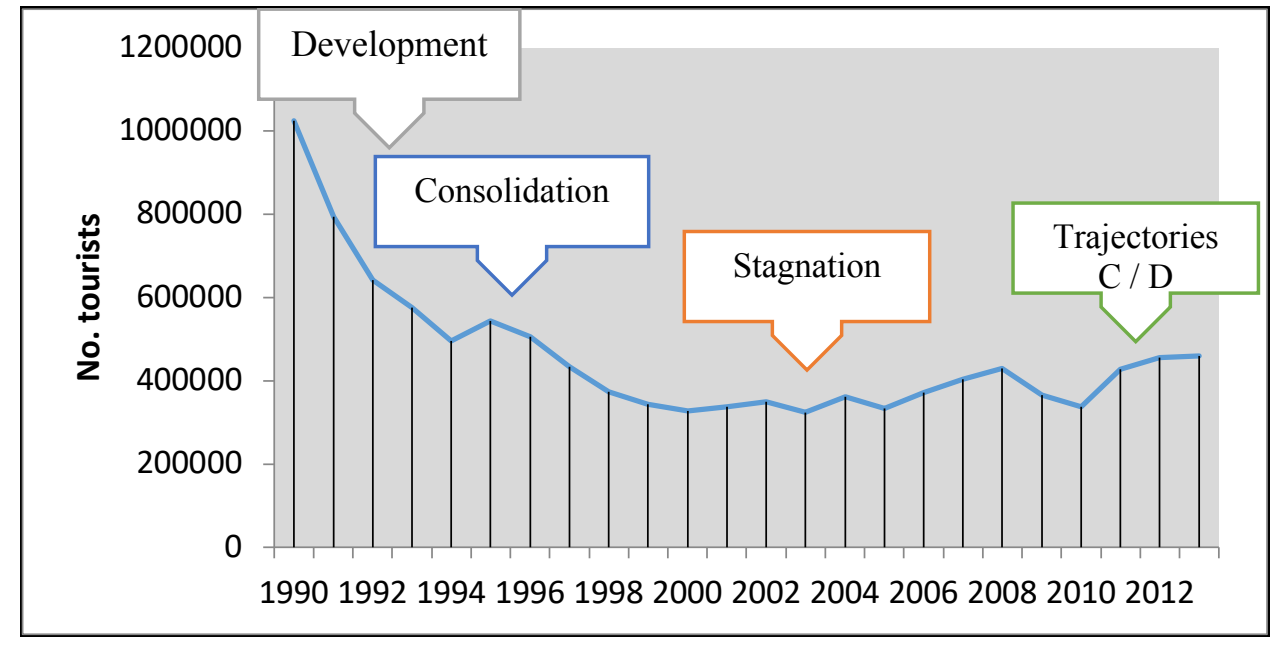

Figure 3 TALC model for Oltenia destination Source: [12]

Destination Oltenia must therefore have an appropriate management of the destination and develop stronger products to become competitive on the national tourist market. The current situation shows a lack of a coherent strategy and destination management. 
Nor others regions enjoy adequate infrastructure for undergoing a performing tourism, naming here the Black Sea Coast (with a non-functional Sun Highway, with no minimum facilities related to physiological needs, to mass services, accommodation, emergency health care, all of which "lacking in perfection"...) or the wonderful Danube Gorge where landslides with serious accidents and incidents, resulting in the loss of life (as in 2004, with the partial flooding of communes of access to the Gorge, such as Eşelniţa) all this stops, hinders the tourist phenomenon, prejudicing it in its natural manifestation.

Not only the tourist attractions, especially the natural ones, become the vector of the tourist flows but also the festive events, the elements of uniqueness, the image of that tourist destination.

To define a destination, it is necessary to create a two-component tourism product in terms of functionality:

- the primary tourism offer - which is based on the tourist attractions of the area, namely, the means, conditions and qualitative characteristics that the tourist uses to engage in a tourist activity,

- the secondary tourist offer, comprising the facilities: transportation, social interaction, travel arrangements, souvenirs, etc.

The tourist products meet the tourist needs (primary needs - making a trip and the secondary ones that come in the package as a travel bonus: accommodation, food etc.) [14] (p.18) and are the objects of transactions between tourists and economic agents in tourism [15] (p. 473). A tourist product is consumed by a tourist during a journey and includes several tangible and intangible elements; its specificity is related to the provision of transport services, accommodation, attractions as well as other facilities for tourists. Jovicic [16] considers that the tourist's needs arise when a trip is made, including traveling outside the residence area. Thus, the tourist product should include natural and man-made resources, tourism infrastructure and also complementary services [17], [18] and meets the requirements of tourists that are different, corresponding to the individual preferences that are born in leisure [19] (p. 96).

The elements of tourist attraction, the tourism resources are divided into three categories: inherited resources (natural and cultural / heritage resources), created resources (specific tourism infrastructure, special events, available activities, leisure, shopping) and factors and support resources (general infrastructure, quality of service, destination accessibility, hospitality and market ties). Together, these factors contribute to the attractiveness of a destination, forming the basis for the destination's competitiveness [20]. 


\section{Attractions}

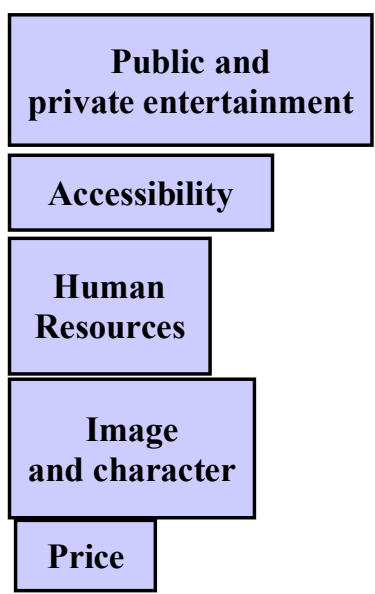

Attractions are diverse and grouped to provide special experiences. They are combined with shopping and catering services etc.

These are often the focus of visitors' attention and can provide the initial motivation for the tourist to visit the destination. They can be: natural, built or cultural.

Figure 4 Attractiveness features specific to a tourist destination Source: adaptation by Dr.Y. Venkat Rao, [21]

Though conceived much later than other development regions, Short-term tourism development strategy (2014), medium (2020) and long (2030), in the Study on regional tourism development includes a vision of the development strategy, and sets out the priorities and typologies of intervention. According to this document, tourism can be considered as a priority for the region's development program, given both the existing resources, as well as the need to achieve economic and social cohesion in the region by expanding the number of areas and resources to be capitalized on the entire territory of the region through an approach based on integration and sustainability. The vision of the strategy: "Tourism will be in the next 20-30 years the framework element of local development, a key factor for raising the standard of living of the population in the Region of SW Oltenia and a pole of attracting investments" [22].

We strongly believe that the tourist phenomenon should not be restricted to natural and anthropic attractions, here the phenomenon of expanding-stretch-based and on the development of the knowledge of competence, on the efficiency of the tourist act, resulting in that "matching", that equilibrium and permanent adaptation to the needs of the tourists, continuously diversifying the tourism products, thus bringing true significance to the tourist destination value chain alongside the diversification of primary and secondary functions in the optics of the two "engines" of the sustainability of a tourist destination: competitiveness and innovation (Figure 5).

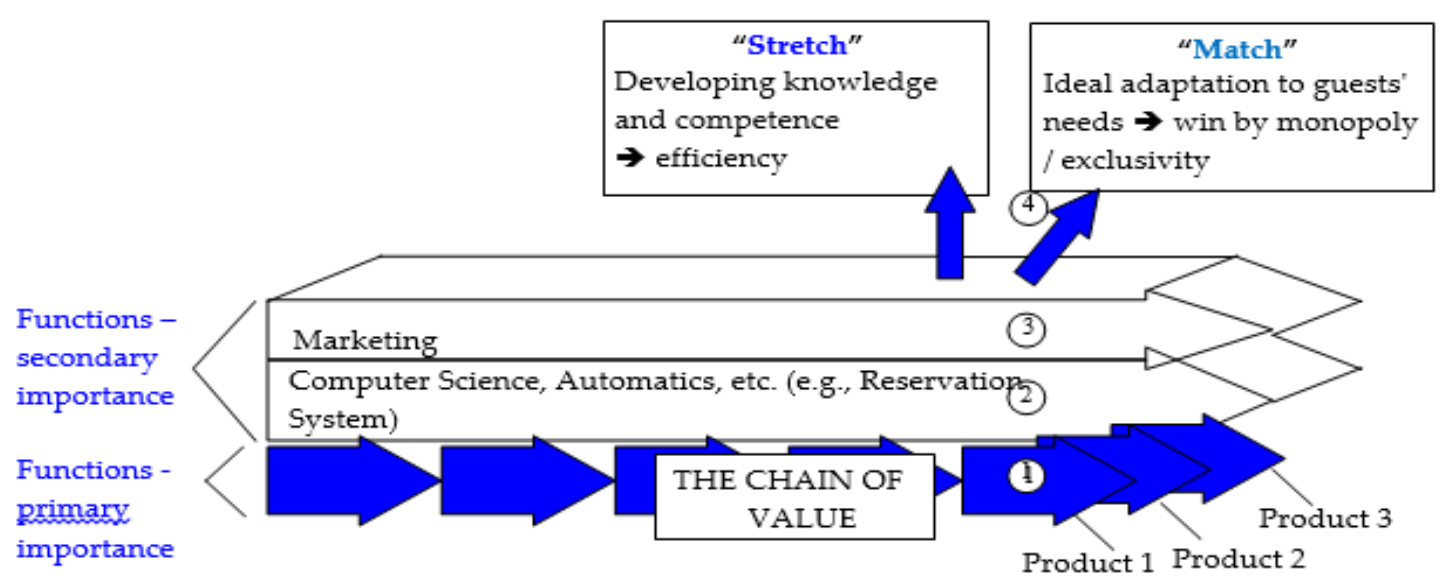

Figure 5 Model of a competitive and innovative tourist destination Source: [23] 


\section{CONCLUSIONS}

Conjunctural conditions are the forces in the environment that limit or influence the competitiveness of the tourist destination. These factors are economic, social, demographic, technological, environmental and political.

Destination management includes public domain activities (growth of national tourism development strategies, destination management organizations, destination planning and development, human resource development, environmental management etc.) and in the private sector (tourism associations, adopting green strategies, developing new products, ecocertification programs etc.).

The conditions of the application take into account the preferences of the tourists, the increase of the level of popularization of the destination, the image of the destination. The model proposed by Dwyer \& Kim [20] assigns an important place to these conditions of tourism demand for determining the competitiveness of a destination, considering that a tourist destination, in order to remain competitive, must develop its tourist products to meet the preferences of tourists, continuously evolving preferences. Becoming and guaranteeing the success of a tourist destination are driven by its ability to provide tourists with an innovative, innovative offer, an experience that has not been lived, exceed the individual expectations of other competing destinations, of course with a clear, precise target of continuous growth of competitiveness (Figure 6).

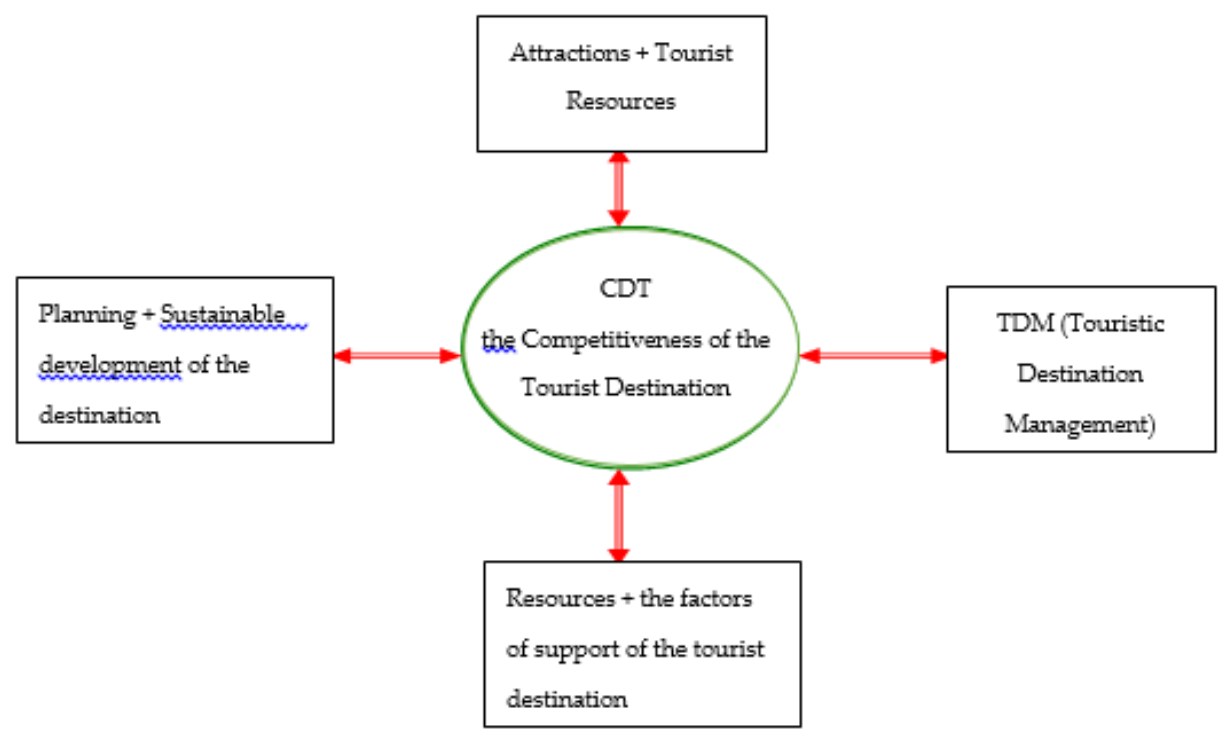

Figure 6 Competitiveness of the Oltenia tourist destination Source: [24]

On the long road that ensures the competitiveness of a tourist region are important mandatory steps, accompanied by specific objectives and strategies, a rigorous management of the tourist destination, planning and sustainable development, all focused on tourism resources and attractions, as factors of destination support travel.

Essentially, from a touristic point of view, competitiveness is "the capacity of a destination to increase travel receipts, attract more and more tourists, providing them with satisfying, memorable experiences and in a most profitable way, while improving the standard of living for the local community and keeping unaltered the destination's natural capital for the next generations" [3]. 
Competitiveness should not be confused with attractiveness, the attractiveness of a destination being an antecedent to competitiveness; a tourist destination can be very attractive, but some factors such as air access, accommodation offer may weaken its competitiveness. Competitiveness and attractiveness characterize a destination from different points of view: from a tourist perspective, it is about attractiveness, while from a destination perspective it is about competitiveness [25]. Although there are many studies on the attractiveness of a destination [26]; [27] or its competitiveness [28], [4], studies that analyze both attributes are quite few [29].

The competitiveness and sustainability of the South-West Oltenia region was achieved in the specific conditions of the tourist destination, taking into account the conditions of the demand (price competitiveness and internal demand) by the complementary conditions (infrastructure specific to tourism in the region of the general infrastructure), all these depending on the existing tourism resources, but also those that will be created, the destination management, the influences of globalization, all of which have as final target the competitiveness of the tourism in the South-West Oltenia Region in certain conjunctural situations, unwanted by tourists and those who want it to compete (economic crisis, floods, etc.).

Sustainable and competitive tourism development in Oltenia is very useful for managers working in tourism but also for those who develop strategies for competitiveness and sustainable development for the tourism sector, for a unique region, a region on the territory of which we meet tourist destinations unmistakable (The Danube Gorge), also revealing the points they need to ask even to stimulate their manifestation and a considerable contribution to the formation of a tourist destination of excellence. (The Danube Gorge can be considered as the region's visiting card, which received the title of "European Destination of Excellence" in 2008). Some theoretical approaches to the image of a competitive tourist destination consider that it can be pre-determined and shaped from the perspective of personal and current experiences ([30], [12], [31], [32], [33], [34], [35]), the investigation and understanding of current tourists provides an information base from which to build and customize marketing and tourism services.

The conceptual model of the competitiveness and sustainability of Oltenia tourism destination, presented in the article (Figure 7), is also analyzed at micro and macro level, taking into account the quality of tourist products, unanimously recognized by the destination policy, its planning and development specific, performance management focused on the sustainable valorisation of resources and tourist attractions.
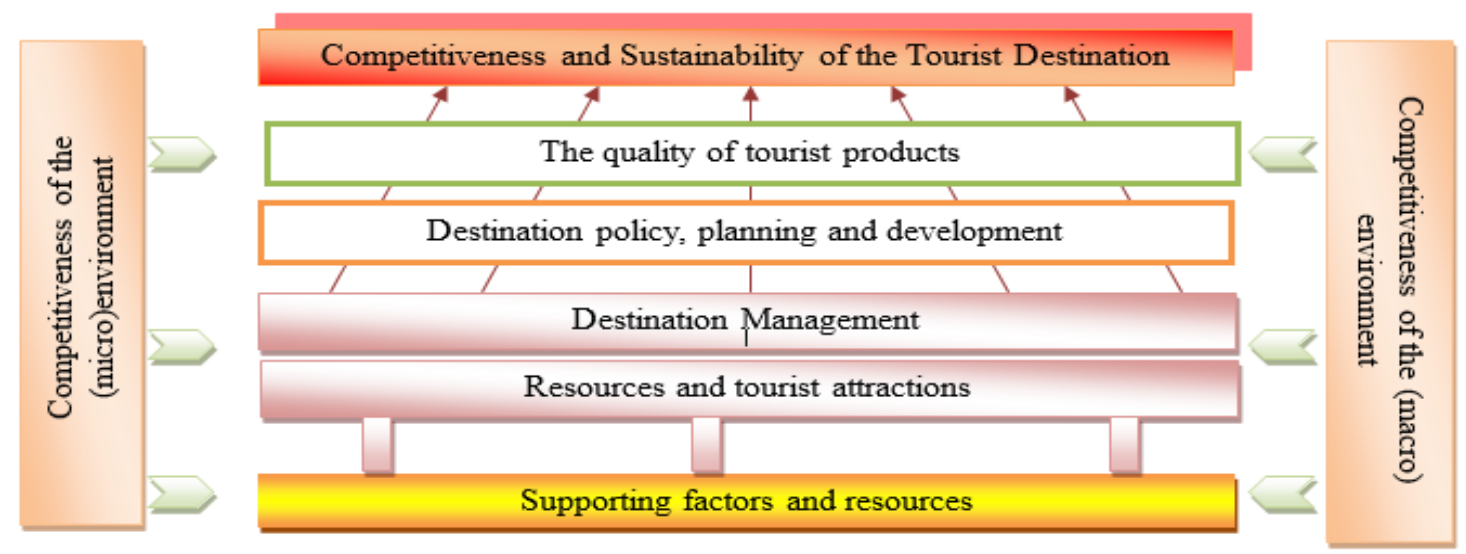

Figure 7 The conceptual model of the tourism destination's competitiveness Source: adaptation by Ritchie and Crouch [36], p.63 
Sometimes, however, tourism in the Oltenian area is mistakenly perceived by the local population and by tourists. Most of the time, the impact of tourism activity on nature or on traditional local communities is not taken into account.

Thus, the ecological education component, responsible for nature and culture is missing as a direct support component of nature conservation or support of traditional activity. In the perception of the population in Oltenia, the existence of protected areas is perceived more as a hindrance than as a facilitator in the development of tourism / ecotourism or for local development.

In order to support the development of tourism in Oltenia, interventions are needed for the development of tourism infrastructure and for the planning of the territory; the development of a specific ecotourism infrastructure will allow for a broader range of services to be offered without having a negative impact on the environment, but also on local communities.

Diversifying hiking, cycling routes, camping sites, building sightseeing centers or tourist information points are just a few of the activities to be undertaken.

Diversification of innovative products in the Oltenia destination, meant to increase and ensure competitiveness, so elements of cultural potential and ethnic mosaics in the region can become innovative, unique tourism products: local, gastronomic and craft fairs, local traditions centers, creation of innovative services for tourists, nonexistent, unfortunately up to present in the area: first aid point, rescue services, children's services and playgrounds, pet-friendly services, cyclotourist parking, beauty services , SPA, specific infrastructure for seniors, etc.

Suitable for the Oltenia tourist destination could be: the permanent pressure of competition on the world tourist market, a flexible and rapid response of tourism-related organizations within the tourist destination to their existence and competition. It is very important to know the foundations and substance of the destination, as well as the trends that will mark its development.

Competitiveness development may be a major force in the research area to explore the role of demand factors in comparing the competitiveness of different destinations. In particular, there are tourists who want to discover new places, reach new, wild, less accessible places and, as a general trend, enjoy special travel experiences. Things that the Oltenia touristic region offers in full, a diversified offer, on all tastes, satisfying all the ages and motivations of the tourists.

\section{References}

European Commission. ec.europa.eu/growth/sectors/tourism/offer/sustainable_en

Crouch, G.I and Ritchie, J.R.B., Tourism, competitiveness, and societal prosperity, Journal of Business Research 44, 137-52, 1999.

Ritchie, J.R. Brent and Crouch, G.I. - The competitive destination: A sustainability perspective. Tourism Management 21 (1), 1-7, 2000.

Hassan - "Determinants of Market competitiveness in an environmentally sustainable tourism Industry,"Journal ofTravel Research, 38(February), 239-45, 2000.

Dupeyras \& MacCallum, - Indicators for Measuring Competitiveness in Tourism,OECD,2013 Author 1, A.B. (University, City, State, Country); Author 2, C. (Institute, City, State, Country). Personal communication, 2012.

Poon A - Tourism, Technology and Competitive Strategies, University of Arizona Press, 1230 North Park Avenue, Tucson, AZ 85719, 1993, p. 352.

Mihalič, T., Environmental management of a tourist destination: A factor of tourism competitiveness, Tourism Management 21, Pergamon, 2000, p. 65 
Mazilu, M., Marinescu, R., Bălă, D., \& Dragomir, L. (2019). Competitiveness And Innovativeness In The Attractiveness Of A Tourist Destination Case Study - Tourist Destination Oltenia. Advances in Social Sciences Research Journal, 6(9) 10-23.

Ritchie, J.R. and Crouch, G.I. - Competitiveness in international tourism: A framework for understanding and analysis. Proceedings of the 43rd Congress of Association Internationale d'Experts Scientifique de Tourisme. San Carlos de Bariloche, Argentina, 17-23 October. 1993.

Candea M, Stancioiu F, Mazilu M, Marinescu R, The Competitiveness of the tourist destination on the future Market, Wseas Transactions on Business and Economics, Issue 7, volume 6, july 2009, p.374-384. http://www.wseas.us/e-library/transactions/economics/2009/29-592.pdf.

Cocean Pompei, Geografia Generală a Turismului (capitolul Resurse turistice), Editura Meteor Press, Cluj Napoca,1996.

Popescu L., Băloi I., Mazilu Mirela, A. Bădiță. Competitiv, durabil, inovativ si identitar in conturarea destinatiei turistice Oltenia, Ed Universitaria, Craiova, 2015, ISBN:978-606-14-0926-6, p.132.

Bădiţă A., Mazilu M., Popescu L., Challenges for human capital and sustainable development of rural areas. A case study on Craiova Metropolitan Area, 22nd Annual Colloquium Commission on the Sustainability of Rural Systems, International Geographical Union "Rural life and rural systems between tradition and integrated urban-rural development", 24 August - 03 September 2014, Bucharest and Sibiu, Romania, 2014, http://www.cicadit.ro/en/events1.html.

Butler, R., Tourism Area Life Cycle: Contemporary Tourism Reviews. Oxford: Goodfellow., and "Tourism and the environment: a geographical perspective,"Tourism Geographies, 2 (3), 337-58, 2011.

Paul, H., "Marketing für Fremdenverkehr: Leitlinien für die Dienstleistungs- und Absatzpolitik im Herstellerbereich der Fremdenverkehrswirtschaft", RKW Rationalisierungs- Kuratorium der Deutschen Wirtschaft, Frankfurt, 1977, p-18.

Koutoulas - Understanding The Tourist Product, Interim symposium of the Research Committee on International Tourism (RC 50) of the International Sociological Association (ISA) on the topic: "Understanding Tourism Theoretical Advances", 14-16 May 2004, University of the Aegean, Mytilini, Greece, p. 473, 2004.

Jovicic - A plea for tourismological theory and methodology, December 1988, Tourism Review 43(3):2-5, D0I: 10.1108/eb057997, 1988.

Cristureanu, Factors Influencing Touristic Demand and its Modelling Possibilities, Procedia - Social and Behavioral Sciences,Volume 62, 24 October 2012, Pages 1184-1189.

Mazilu Mirela Elena, Turism şi Dezvoltare Durabilă, Editura Universitaria Craiova, 2011.

Leiper, - Tourist attractions systems, Annals of Tourism Research,Volume 17, Issue 3, 1990, Pages 367-384, p. 96.

Dweyer \& Kim, Destination Competitiveness: Determinants and Indicators, Routledge, Current Issues in Tourism 6(5), 2003.

Y. Venkat, R., Destination Planning and Development, Paper Code : MBTM 3004, MBA - TOURISM, III Semester, ISBN No. 978-93-81932-09-4

ADR Oltenia, 2010 - Studiu privind dezvoltarea turismului la nivel regional, https://www.adroltenia.ro/wpcontent/uploads/2014/05/STUDIU-TURISM-FINAL.pdf.

Mazilu M, Dumitrescu D, Bădiță A, Towards sustainable tourism development. Strategica. Opportunities and Risks in the Contemporary Business Environment: 1017-1029, Editura Tritonic, București, 2016

Mazilu, M., Sustainable Tourism of Destination, Imperative Triangle Among: Competitiveness, Effective Management and Proper Financing. 10.5772/28062, Sustainable Development - Policy and Urban Development Tourism, Life Science, Management and Environment, 2012

Buhalis, D., Marketing the competitive destination in the future. Tourism Management 21 (1), 97-116, 2000.

Formica; "Measuring Destination Attractiveness: A proposed Framework" in International Business Conference. Miami, Florida: TTRA, 2001.

Hu and Ritchie - Measuring destination attractiveness: A contextual approach,"Journal of Travel Research, Fall, 2534, 1993.

Kozak and Rimmington - Measuring tourist destination competitiveness: Conceptual considerations and empirical findings, September 1999, International Journal of Hospitality Management 18(3):273-283, DOI: 10.1016/S0278-4319(99)00034-1, 1999.

Vengesayi - A conceptual model of tourism destination competitiveness and attractiveness, 2003.

Crompton, J. L., Motivations for pleasure vacation. Annals of Tourism Research,6(4), 1979, p.408-424 
Mitroi (Gheorgheci), S., Identitate,Competitivitate Și Durabilitate În Conturarea Microregiunii Turistice Clisura Dunării, teză de doctorat, 2017

Mazilu Mirela Elena, Popescu Liliana, Amalia Bădiță, "Ingredients" for an attractive Tourism market", participare la Conferința Internațională Turism și Dezvoltare Durabilă, organizată de Fac de Marketing Turistic, Dimitrie Cantemir, Timișoara, publicat în Revista QUAESTUS, Editura Eurostampa, Timișoara, ISSN-L 2285-424X, 2014, p.38-40.

Mazilu Mirela Elena. Innovation,tradition and cooperation in tourism according to the EU Stategy of the Danube Region, Proceedings of International Conference Serbia in the Danube Region in 21-st Century,ISBN:978-86-7067200-0, Publisher Institute of International Politics and Economics, Belgrad, 2014, p.73-94.

Mazilu, M., Nedelcu, A., The Romania-Bulgaria-Serbia Cross-Border Touristic Potential Specific for the South-West Oltenia Region According to the Danube Strategy Approach, : Environment and Ecology at the Beginning of 21st Century, Chapter 52, ST. KLIMENT OHRIDSKI UNIVERSITY PRESS SOFIA, 2015

Mirela Mazilu, Loredana Dragomir, Andrei Băbăț, Carlo Dragomir, Innovative / Competitive Tourist Product In Revitalizing A Tourist Destination. Case Study: The Danube Cluster, publicat în Proceedings of the 9th International Conference of Doctoral Students and Young Researchers, ISBN 978-606-10-2011-9, Oradea, No. 6, December 2018, p. 161 - 164

http://steconomiceuoradea.ro/wp/wp-content/uploads/2014/01/Volum-doctoranzi-2018.pdf

Crouch, G.I and Ritchie, J.R.B, The Competitive Destination: A Sustainable Tourism Perspective, CABI Publishing, 2003, p.63

Baker, M. J.. Critical success factors in destination marketing, in Tourism and Hospitality Research, Palgrave Macmillan, 2008, Vol. 8, No. 2 p. 79-97.

Cater, E.. Environmental contradictions in sustainable tourism. Geographical Journal 161 (1), 1995, p. 21-28.

Edgell D.L.. Managing Sustainable Tourism: A Legacy for the Future, Routledge, 2006, p.135.

Gartner, W.C.. Image Formation Process, in Journal of Travel and Tourism Marketing, 2(2/3), 2009, p.191-215.

Grgona, J.. Tourism and Ecology, Annals of DAAAM \& Proceedings, 2009.

Jafari, J., Wall G.. Sustainable tourism. Annals of Tourism Research 21(3): 667-669, 1994.

Mazilu, M.E.. Les stratégies pour un tourisme durable et ses effets, Problems of Geography, nr. 1-2, Bulgarian Academy of Science, 2006.

Mirela Mazilu, Daniela Dumitrescu, Mădălina Andrei, Roxana Marinescu, Tasks of a New Sustainable Romanian Model Destination, INTERNATIONAL JOURNAL OF SYSTEMS APPLICATIONS, ENGINEERING \& DEVELOPMENT, Vol.11, 2017, p.26-31-44.

Mirela Mazilu. Sustainable Tourism of Destination, Imperative Triangle Among: Competitiveness, Effective Management and Proper Financing, Sustainable Development - Policy and Urban Development - Tourism, Life Science, Management and Environment, Chaouki Ghenai (Ed.), 2012, ISBN: 978-953-51-0100-0, InTech, DOI:10.5772/28062

Lagiewski, R., The Application of the Talc model: a literature survey., Aspects of Tourism: The Tourism Area Life Cycle Vol.1, Applications and Modifications. Ed. Richard Butler. Great Britain: Cromwell Press, 2006. 27-50

Mirela Mazilu, Cipriana Sava, Amalia Niță, Sabina Gheorgheci,A Green and Competitiveness Model DevelopmentDanube Bend-Eco-Friendly Destination, INTERNATIONAL JOURNAL OF SYSTEMS APPLICATIONS, ENGINEERING \& DEVELOPMENT,Vol.11,2017,p.32-ISSN: 2074-1308 44, 2017, http://www.naun.org/main/UPress/saed/2017/a142014-032.pdf

Mazilu Mirela, Roxana Marinescu, Bălă Dumitru, Loredana Dragomir, Aspects regarding the competitiveness and innovativeness of the tourist destination, Proceedings ISSD, Proceediings of the Internatiionall Conference "Informatiion Sociiety and Sustaiinablle Devellopment"ISSD 2019VIth Edition, May 10-11, 2019 TarguJiu, Gorj County, Romania, , „ACADEMICA BRÂNCUŞI” PUBLISHER, ISBN 978-973-144-889-3 ,2019, p.147-152 